\title{
Precerebellin-related genes and precerebellin 1 peptide in the adrenal gland of the rat: Expression pattern, localization, developmental regulation and effects on corticosteroidogenesis
}

\author{
MARCIN RUCINSKI, AGNIESZKA ZIOLKOWSKA, MARTA SZYSZKA and LUDWIK K. MALENDOWICZ \\ Department of Histology and Embryology, Poznan University of Medical Sciences, Poznan, Poland
}

Received October 16, 2008; Accepted December 4, 2008

DOI: 10.3892/ijmm_00000140

\begin{abstract}
Precerebellin (Cbln)-related peptides are known to modulate the secretory activity and growth of the adrenal gland. However, precise expression of the Cbln-related genes and Cbln1 peptide in the adrenal remains unclear. Therefore, we investigated, using RT-PCR, QPCR, Western blotting, immunohistochemistry and hormonal assays, their expression in the adrenals of adult rats and in the course of postnatal ontogenesis. Of the 4 known Cblns, Cbln(1-3) mRNAs were found in the adrenal gland of the adult male rats. Expression patterns of Cbln 1 and 3 were similar to each other and different from that of Cbln2. Highest expression of the Cbln1 and 3 genes was observed in the zona glomerulosa (ZG), lower expression was noted in the fasciculata/reticularis and lowest expression was observed in the adrenal medulla. Expression of these genes was also present in freshly isolated rat adrenocortical cells. On the contrary, by means of classic RT-PCR, we demonstrated the presence of mRNAs of $C B L N(1-4)$ in the human adrenal gland. In the rat, highest expression of the Cbln1 and 3 genes was found at postnatal day 2 and was somewhat lower at day 90. On the contrary, expression of the Cbln2 gene was low in adrenals of 2-day-old rats and notably higher at the remaining time points studied (up to day 360). Cerebellin (CER)-like immunoreactivity was observed in the membranes of the adrenal ZG cells, while in the medulla, immunoreactive substances were localized primarily in the cytoplasm of chromaffin cells. Cbln1-like immunoreactivity was present mainly in the cortex of the gland, and reaction products were noted both in the membranes and cytoplasm of
\end{abstract}

Correspondence to: Professor Ludwik K. Malendowicz, Department of Histology and Embryology, Poznan University of Medical Sciences, 6 Swiecicki St., 60-781 Poznan, Poland E-mail: 1km@amp.edu.pl

Abbreviations: Cbln, precerebellins; Cbln1-4, precerebellin 1-4; CER, cerebellin; desCER, des-Ser1-cerebellin

Key words: precerebellin, cerebellin, adrenal, quantitative polymerase chain reaction, protein expression, aldosterone, corticosterone, rat, human adrenocortical cells. Semiquantitative evaluation of Cbln1 protein expression in compartments of the adrenal gland of the adult rat revealed a higher concentration of Cbln1 protein in the cortex than in the medulla of studied rats. We also found that both CER and desCER stimulated basal aldosterone secretion by freshly isolated ZG cells. Thus, the present study provided precise data on expression of the Cbln-related genes and Cbln1 peptide in the adrenal gland of the rat and on their developmental regulation. We also found that, contrary to the human adrenal, in the rat adrenal gland, the Cbln4 gene was not expressed at the mRNA level.

\section{Introduction}

The two polypeptides isolated in 1984 from the rat cerebellum, a hexadecapeptide cerebellin (CER) and its N-terminal truncated version, des-Ser1-cerebellin (desCER), are derived from a larger precursor called precerebellin1 (Cbln1) $(1,2)$. Progress in molecular biology methods has allowed identification of the entire subfamily of precerebellins (Cblns), which comprises four propeptides named Cbln1-4 (2-6). Cbln-related genes are located at different chromosomes, and Cblnencoded proteins are highly conserved $(4,7,8)$. All of them are highly expressed in the central nervous system, particularly in the cerebellum.

Precerebellins belong to the $\mathrm{C} 1 \mathrm{q} / \mathrm{TNF}$ superfamily of secreted proteins and, like other members of the family, they may form homomeric and also heteromeric complexes with each other in vitro (6-12). At present, Cbln are recognized as a new class of transneuronal regulators of synapse development and synaptic plasticity in various brain regions $(6,8)$. With great probability this action depends on direct paracrine effects of Cbln complexes on adjacent synapses or nervous cells. However, it cannot be excluded that some Cbln-related transneuronal effects may be mediated by CER and/or desCER.

Cbln and CER are also present in extracerebral tissues, with relatively high concentrations in the adrenal gland (reviewed in ref. 13). However, Cbln 1 mRNA was not detected in normal human adrenal glands using Northern blot analysis or by reverse transcription followed by polymerase chain reaction $(2,8,14,15)$. In this regard, recently, we demonstrated expression of Cbln1-3 in classic endocrine glands of the rat (16). Since both CER and desCER are known 
Table I. Conventional RT-PCR and QPCR analyses of precerebellin expression in the rat adrenal gland. ${ }^{\mathrm{a}}$

\begin{tabular}{llclc}
\hline cDNA & $\begin{array}{c}\text { Genbank } \\
\text { accession no. }\end{array}$ & $\begin{array}{c}\text { Primer } \\
\text { or probe }\end{array}$ & \multicolumn{1}{c}{ Primer or probe sequence (5'-3') } & $\begin{array}{c}\text { Position } \\
\text { PCR product } \\
\text { size (bp) }\end{array}$ \\
\hline Cbln1 & XM 001067551 & S & CCCTACGGGCACTGCTCTG & $144-162$ \\
& & A & CTGCGTTCTGAGTCAAAGTTG & $294-314$ \\
& Probe & CTGCCATC & $203-210$ \\
Cbln2 & NM 001012740 & S & TGGCCTTCTCCGCTACTC & $457-474$ \\
& & A & CGAGGCAAGGTCAAAGTGGT & $556-575$ \\
& & Probe & TGAGCAAC & $502-509$ \\
Cbln3 & XM 001056593 & S & ACCATGAACCAGCAGGAGAA & $483-502$ \\
& & A & AAAGCCACCGCCCTCATT & $551-568$ \\
& & Probe & TGCGATCT & $523-531$ \\
Cbln4 & XM 001053640 & S & GAGCAACAAGACTCGCATCAT & $1859-1879$ \\
& & A & CAAAGACGGATTCCAGTGTG & $1919-1938$ \\
& & Probe & CTGGTTAA & $1896-1903$ \\
\hline
\end{tabular}

${ }^{a}$ Oligonucleotide sequences for sense (S) and antisense (A) primers as well as the sequence of the probes is shown.

to affect adrenocortical function, the present study aimed to characterize expression of precerebellin-related genes and precerebellin 1 peptide in the adrenal gland of the rat. We focused on their expression pattern, localization within the gland, their developmental regulation and effects of CER and desCER on corticosteroidogenesis.

\section{Materials and methods}

Animals and reagents. Studies were performed on rats of the Wistar strain from the Animal Center of the Poznan University of Medical Sciences. Animals were maintained under standardized conditions of light $(14: 10 \mathrm{~h}$ light-dark cycle, illumination onset $06: 00)$ at $23 \pm 2^{\circ} \mathrm{C}$ with free access to standard pellets and tap water. Rats were sacrificed by decapitation. The Local Ethics Committee for Animal Studies approved the study protocol. Cerebellin and des-cerebellin were purchased from Bachem Feinchemikalien AG (Bubbendorf, Switzerland) and ACTH (Synacthen) from Ciba (Basel, Switzerland). If not otherwise stated, all other chemicals and reagents were provided by Sigma-Aldrich (St. Louis, MO, USA) or POCh (Gliwice, Poland).

Isolated adrenocortical cells. Adrenal glands from intact male rats were decapsulated to separate the zona glomerulosa (ZG) from the zonae fasciculata and reticularis $(\mathrm{ZF} / \mathrm{R})$. Dispersed cells were obtained by collagenase I digestion and mechanical disaggregation (17-23). Dispersed cells obtained from 6-8 rats were pooled to obtain a single-cell suspension, and 6 cell suspensions were employed for each incubation experiment. Cells were counted with the CASY-Cell Counter and Analyser Systems, Model TT (Schaerfe System GmbH, Reutlingen, Germany). Aliquots of each cell suspension $\left(10^{4}\right.$ cells $/ \mathrm{ml}$ in Krebs-Ringer bicarbonate buffer with $0.3 \%$ glucose and $0.2 \%$ bovine serum albumin) were incubated with various $\mathrm{CER}$ and desCER concentrations in the presence or absence of ACTH $\left(1 \times 10^{-7} \mathrm{~mol} / \mathrm{l}\right)\left(\right.$ Cortrosyn $^{\circledR}$; Organon, West Orange, $\mathrm{NJ})$. The incubation was carried out in a shaking bath at $37^{\circ} \mathrm{C}$ for $60 \mathrm{~min}$ in an atmosphere of $95 \% \mathrm{O}_{2}$ and $5 \% \mathrm{CO}_{2}$. At the end of the experiment, the incubation tubes were centrifuged at $4^{\circ} \mathrm{C}$, and the supernatant was stored at $-36^{\circ} \mathrm{C}$.

Conventional RT-PCR and QPCR. The methods applied were described previously $(6,24-28)$. Briefly, from fragments of adrenals or from isolated adrenocortical cells, total RNA was extracted by a method using Tri Reagent (Sigma) and purified on columns (RNeasy Mini Kit, Qiagen). Contaminating DNA was eliminated by DNase-I treatment (RNase-Free DNase Set; Promega, Madison, WI). RT was performed using AMV reverse transcriptase (Promega) with oligo dT (PE Biosystems, Warrington, UK) as primers. The reaction was performed at $42^{\circ} \mathrm{C}$ for $60 \mathrm{~min}$ (Uno II Thermocycler, Biometra). Quality of the obtained product was evaluated by electrophoresis in $1 \%$ agarose gel with ethidium bromide. Primers for studies of precerebellin gene expression (Table I) and reference genes (Table II) were purchased from the Laboratory of DNA Sequencing and Oligonucleotide Synthesis, Institute of Biochemistry and Biophysics, Polish Academy of Sciences, Warsaw. For all tested genes, 34 cycles of the following sequences were applied: denaturation at $94^{\circ} \mathrm{C}$ for $30 \mathrm{sec}$, annealing at $58^{\circ} \mathrm{C}$ for $60 \mathrm{sec}$ and extension at $68^{\circ} \mathrm{C}$ for $60 \mathrm{sec}$. In control reactions, water (instead of cDNA) and omission of reverse transcriptase (-RT) were used. Reaction products were separated on ethidium bromide-containing $2 \%$ agarose gel and photographed in a transilluminator. QPCR was performed in a Lightcycler 2.0 Instrument (Roche) with software version 4.0. Two methods were applied: the SYBR green and TaqMan-based detections (the probe sequences are shown in Tables I and II). In the SYBR green method the obtained products were characterized by their melting point (precision $0.1^{\circ} \mathrm{C} / \mathrm{sec}$ ). Data were normalized in relation to expression of the reference genes. 
Table II. QPCR analyses of reference gene expression in the studied organs of the rat. ${ }^{\mathrm{a}}$

\begin{tabular}{|c|c|c|c|c|c|}
\hline cDNA & $\begin{array}{c}\text { Genbank } \\
\text { accession no. }\end{array}$ & $\begin{array}{l}\text { Primer } \\
\text { or probe }\end{array}$ & Primer or probe sequence $\left(5^{\prime}-3^{\prime}\right)$ & Position & $\begin{array}{l}\text { PCR product } \\
\text { size (bp) }\end{array}$ \\
\hline \multirow[t]{2}{*}{ TATA box-binding protein } & \multirow[t]{2}{*}{ NM 001004198} & $\mathrm{~S}$ & ATCСТTCACCAATGACTCCTATG & $618-640$ & \multirow[t]{2}{*}{190} \\
\hline & & A & ATGATGACTGCAGCAAACC & $789-807$ & \\
\hline \multirow[t]{2}{*}{ GAPDH } & \multirow[t]{2}{*}{ XM 001073242} & $\mathrm{~S}$ & CCACAGTCCATGCCATCACT & $33-52$ & \multirow[t]{2}{*}{106} \\
\hline & & A & TGGTAACCAGGTGTCCGATA & $119-138$ & \\
\hline \multirow[t]{2}{*}{ B-actin } & \multirow[t]{2}{*}{ NM 031144} & $\mathrm{~S}$ & TGAACACGGCATTGTAACCA & 294-313 & \multirow[t]{2}{*}{300} \\
\hline & & A & AGCGCGTAACCCTCATAGAT & $574-593$ & \\
\hline \multirow[t]{2}{*}{ B 2 microglobulin } & \multirow[t]{2}{*}{ NM 012512} & $\mathrm{~S}$ & ACCGAGACCGATGTATATGC & 284-303 & \multirow[t]{2}{*}{137} \\
\hline & & A & ACCGGATCTGGAGTTAAACTG & $400-420$ & \\
\hline \multirow[t]{2}{*}{ PBGD } & \multirow[t]{2}{*}{ NM 013168} & $\mathrm{~S}$ & GAAAGACCCTGGAAACCTTG & $397-416$ & \multirow[t]{2}{*}{148} \\
\hline & & A & TGCTCATCCAGCTTCCGTA & $526-544$ & \\
\hline \multirow[t]{2}{*}{ HPRT } & \multirow[t]{2}{*}{ NM 012583} & $\mathrm{~S}$ & CAGTCAACGGGGGACATAAAAG & $391-412$ & \multirow[t]{2}{*}{146} \\
\hline & & A & ATTTTGGGGCTGTACTGCTTGA & $515-536$ & \\
\hline
\end{tabular}

${ }^{a}$ Oligonucleotide sequences for sense (S) and antisense (A) primers are shown. GAPDH, glyceraldehyde 3-phosphate dehydrogenase; PBGD, porphobilinogen deaminase; HPRT, hypoxanthine-guanine phosphoribosyltransferase.

Table III. Conventional RT-PCR analyses of precerebellin expression in the human adrenal gland. ${ }^{\mathrm{a}}$

\begin{tabular}{llclc}
\hline cDNA & $\begin{array}{c}\text { Genbank } \\
\text { accession no. }\end{array}$ & $\begin{array}{c}\text { Primer } \\
\text { or probe }\end{array}$ & \multicolumn{1}{c}{ Primer or probe sequence (5'-3') } & $\begin{array}{c}\text { Position } \\
\text { PCR product } \\
\text { size (bp) }\end{array}$ \\
\hline CBLN1 & NM_004352 & S & GAACGCAGCACTTTCATCG & $637-655$ \\
& & A & GGTCGCCTTTCTCCATTTG & $817-835$ \\
CBLN2 & NM_182511 & S & ATATTAAGACTTGGAGGGAATTGG & $386-409$ \\
& & A & CGCCTGTGAACCTGGAAC & $551-568$ \\
CBLN3 & NM_001039771 & S & ATGAGCCAGCAGGGGAAAC & $716-734$ \\
& & A & TCCAAGGGCAGTAGCACAG & $974-992$ \\
CBLN4 & NM_080617 & S & ACCAGAGCCAAACTATCCAG & $1174-1193$ \\
& & A & CAGCCTCCAACCAAATTACC & $1329-1348$ \\
\hline
\end{tabular}

aOligonucleotide sequences for sense (S) and antisense (A) primers are shown.

cDNA from the normal human adrenal cortex was obtained from the late Professor Gastone G. Nussdorfer, Department of Anatomy and Physiology, Padua University, Padua, Italy. Oligonucleotide sequences for sense and antisense primers of CBLN1-4 are shown in Table III.

Western blotting. Western blot analysis was used to identify the Cbln1 protein as previously described (16). The applied primary antibody was anti-Cbln1 (ProSci Inc., San Diego, CA, USA) and secondary horseradish peroxidase-conjugated anti-rabbit IgG (Sigma, St. Louis, MO, USA). The target protein was detected by ECL Advance Western Blotting Detection Kit (Amersham). The chemiluminescence signal was transferred on CL-XPosure Film (Pierce Biotechnology), and the developed film was scanned densitometrically. For data normalization, GAPDH protein was detected on the same membranes after stripping procedure.

Immunohistochemistry (IHC). Adrenals were fixed in Bouin's solution for $24 \mathrm{~h}$, embedded in paraffin and sectioned at 5-6 $\mu \mathrm{m}$. The sections were deparaffinized, and immunohistochemical reactions were performed as detailed previously (16). The following antibodies were used: rabbit antiCER serum (no. 6171-8-23, a generous gift of Professor Kazuhiro Takahashi, Department of Molecular Biology and Applied Physiology, Tohoku University School of Medicine, Japan) or Cbln1 antiserum (TCS Cellworks, ZIB). Negative controls were carried out by similarly treating adjacent 


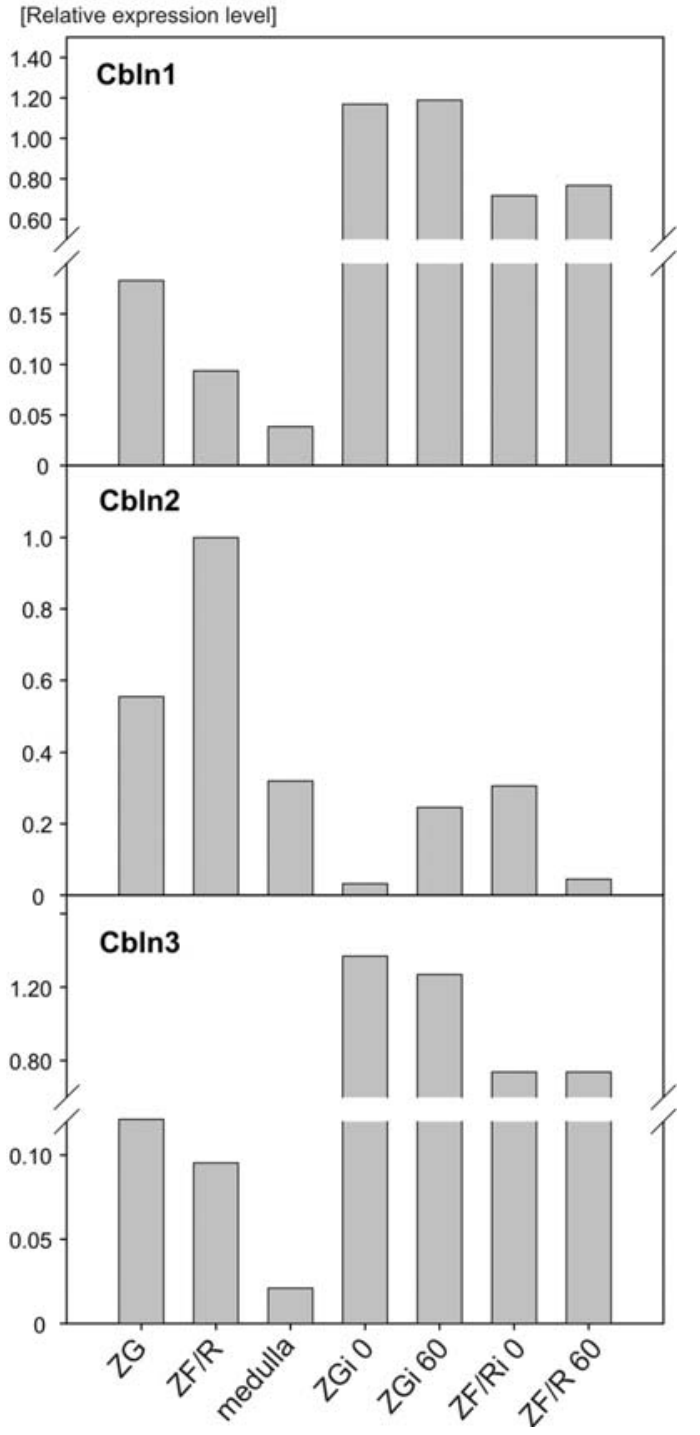

Figure 1. QPCR analyses of precerebellin 1-3 (Cbln1-3) gene expression in individual compartments of the adult male rat adrenal gland and isolated adrenocortical cells. ZG, zona glomerulosa; ZF/R, zona fasciculata/ reticularis; medulla, adrenal medulla. $\mathrm{ZGi} 0$ and $\mathrm{ZF} / \mathrm{Ri} 0$, freshly isolated cells; ZGi 60 and ZF/R 60, cells incubated for $60 \mathrm{~min}$ in KRBG medium. Bars represent relative expression of the studied genes in relation to expression of the HPRT gene; the means from 2 independent analyses.

sections and omitting the primary antibody, as well as using the primary antibody preabsorbed with antigen excess. Some of the sections were counterstained with hematoxylin.
Hormone assay. Concentrations of aldosterone and corticosterone were measured by radioimmunoassay (RIA) using $\left[1,2,6,7-{ }^{3} \mathrm{H}\right]$-aldosterone and $\left[1,2,6,7-{ }^{3} \mathrm{H}\right]$-corticosterone (Amersham, UK) (SA, $1.96 \mathrm{Tbq} / \mathrm{mmol})$ and antisera developed in the rabbit (Sigma) $(25,29-32)$. Aldosterone RIA sensitivity was $5 \mathrm{pg} / \mathrm{ml}$, cross reactivity: aldosterone, $100 \%$; 17 -iso-aldosterone and other steroids, $<0.1 \%$. Intraassay and inter-assay variations amounted to 5 and $7 \%$, respectively. Corticosterone RIA sensitivity was $50 \mathrm{pg} / \mathrm{ml}$, cross-reactivity: corticosterone and cortisol, 100\%; 11 deoxycorticosterone and progesterone, $2 \%$, other steroids, $<0.001 \%$. Intra-assay and inter-assay variations amounted to 7 and $9 \%$, respectively.

Statistics. Data are expressed as the means \pm SEM, and statistical comparison was carried out using the unpaired Student's t-test.

\section{Results}

By means of the QPCR method, we investigated expression of the Cbln genes in individual components of the rat adrenal gland. As shown in Fig. 1, of the 4 known Cblns, Cbln(1-3) mRNAs were present in the adrenal gland of the adult male rats. Expression patterns of Cbln 1 and 3 were similar to each other while different from that of Cbln2. Highest expression of the Cbln 1 and 3 genes was observed in the ZG, lower expression in the $\mathrm{ZF} / \mathrm{R}$ and the lowest in the adrenal medulla. Likewise, in freshly isolated cells and in cells incubated for $60 \mathrm{~min}$, expression of these genes was higher in $\mathrm{ZG}$ than in $\mathrm{ZF} / \mathrm{R}$ cells. On the contrary, Cbln 2 gene expression was the highest in the $\mathrm{ZF} / \mathrm{R}$, while lower in the $\mathrm{ZG}$ and adrenal medulla. In freshly isolated ZG cells, expression of this gene was markedly low, but increased after incubation in KRBG, while opposite results were obtained in the $\mathrm{ZF} / \mathrm{R}$ adrenocortical cells.

On the contrary, in 3 human adrenal glands we demonstrated the presence of mRNAs of $C B L N(1-4)$ by means of classic RT-PCR (Fig. 2).

We investigated expression of the Cbln1-4 genes in the rat adrenal cortex during the course of postnatal ontogenesis, from days 2 to 360 (days 2, 28, 45, 60, 90 and 360). In the adrenals of the developing rats again we identified only Cbln1-3 mRNAs, while that of Cbln4 was absent (Fig. 3). QPCR revealed highest expression of the Cbln 1 and 3 genes at postnatal day 2 and a somewhat lower expression at day 90 (Fig. 4). On the contrary, expression of the Cbln2 gene was

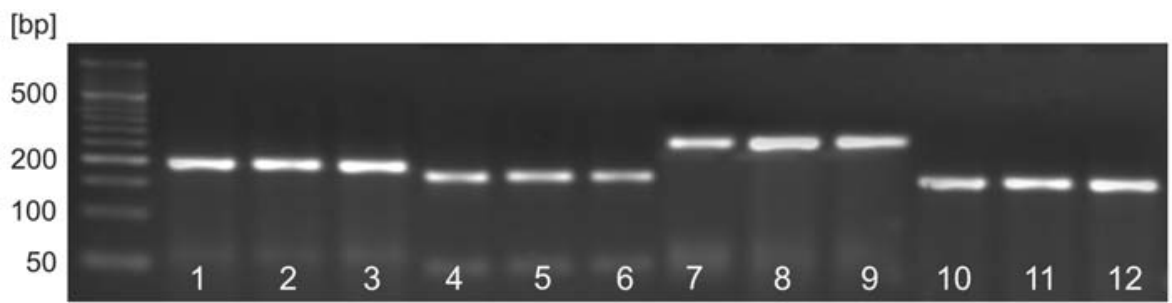

Figure 2. Expression of precerebellin 1-4 (CBLN1-4) genes in the human adrenal gland. PCR products visualized by gel electrophoresis and stained with ethidium bromide. Lanes 1-3, CBLN1; 4-6, CBLN2; 7-9, CBLN3; and 10-12, CBLN4. Amplification of RNA by RT-PCR with the selective primer yielded the expected size of the RT-PCR products (Table III). 

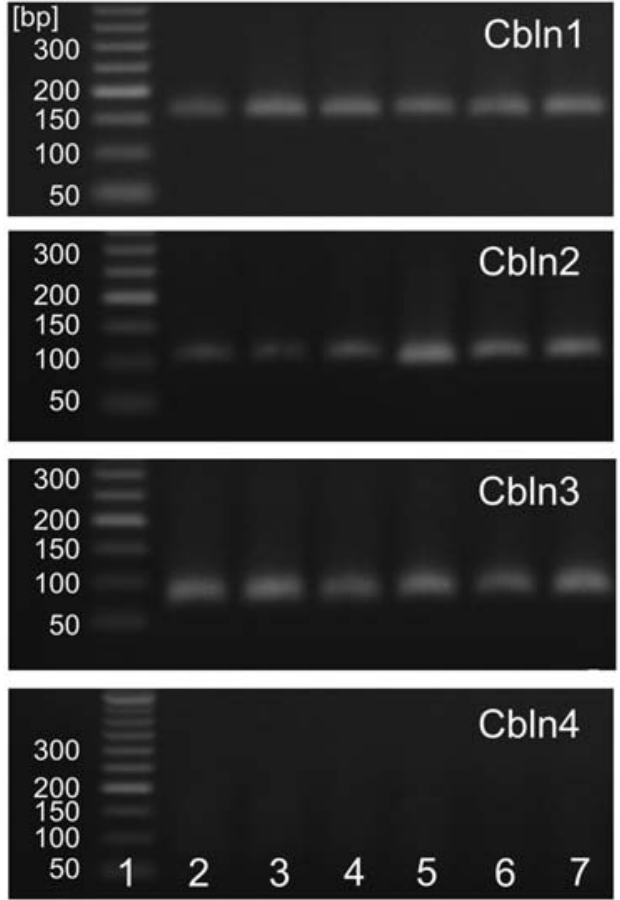

Figure 3. Expression of precerebellin 1-4 (Cbln1-4) genes in the rat adrenal cortex during postnatal ontogenesis. PCR products were visualized by gel electrophoresis in $2 \%$ agarose gel and stained with ethidium bromide. Amplification of RNA by RT-PCR with the selective primer yielded the expected size of the RT-PCR products. Lane 1, DNA ladder; 2, day 2; 3, day $28 ; 4$, day $45 ; 5$, day $60 ; 6$, day 90 ; and 7 , day 360 .

low in the adrenals of 2-day-old rats and notably higher at the remaining time points studied.

Localization of CER- and Cbln1-like substances in the cerebellum and adrenals of adult male rats was studied by means of immunohistochemistry. In the cerebellum, CER-like immunoreactivity was present in perikaryon of Purkinje cells (Fig. 6). On the other hand, immunoreactivities for both CER and Cbln were noted in axons of Purkinje cells. CER-like immunoreactivity was also observed in the membranes of the adrenal ZG cells, while in the medulla these substances were localized primarily in the cytoplasm of chromaffin cells. Cbln1-like immunoreactivity was present mainly in the cortex of the gland, and the reaction products were noted both in the membranes and cytoplasm of adrenocortical cells. Semiquantitative evaluation of Cbln 1 protein expression in

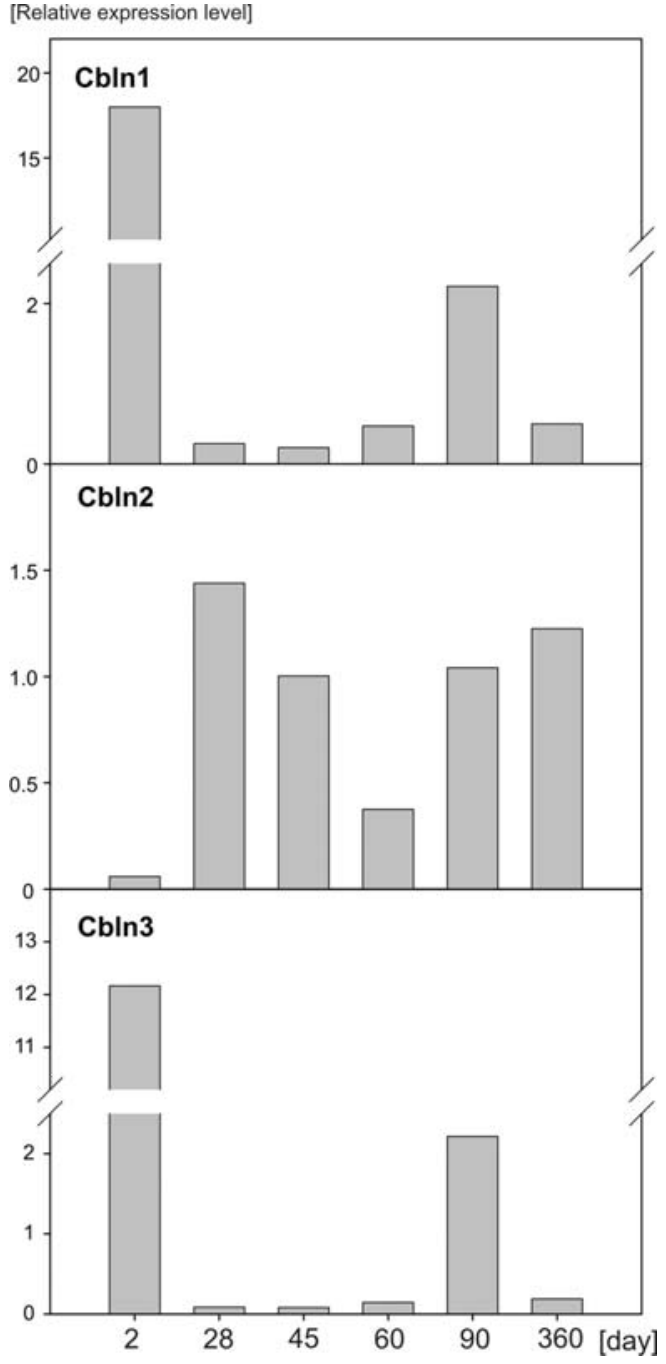

Figure 4. QPCR analyses of precerebellin 1-3 (Cbln1-3) gene expression in the rat adrenal cortex during postnatal ontogenesis (from postnatal day 2 to 360). Bars represent relative expression of the studied genes in relation to expression of the HPRT gene; the means from 2 independent analyses.

compartments of the adrenal gland of the adult rats revealed a higher concentration of Cbln1 protein in the cortex than in the medulla (Fig. 5). In order to examine the association of Cbln1 with the cell membrane, proteins from fragments of the adrenal cortex were extracted either with RIPA or Tris buffer.
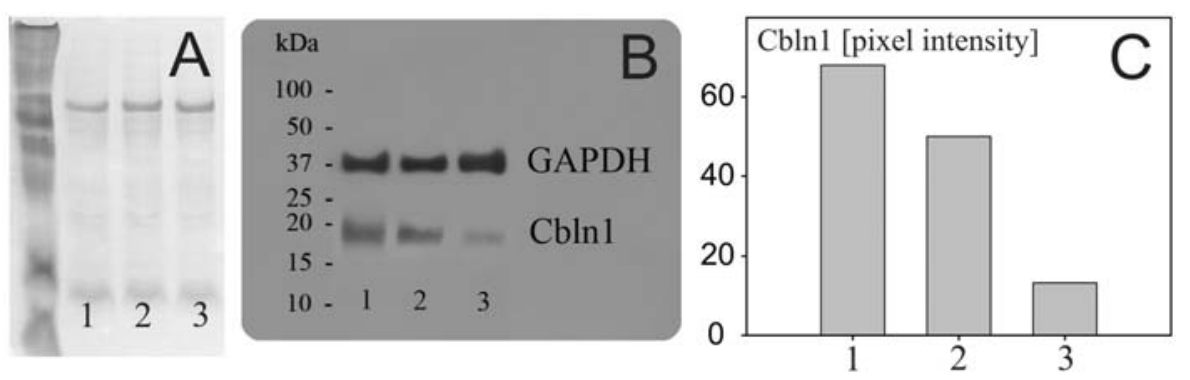

Figure 5. Semiquantitative evaluation of Cbln1 protein expression in compartments of the adrenal gland of the adult rat. (A) Western blotting. Proteins stained with Ponceau S. (B) Chemiluminescence signals of Cbln1 and GAPDH proteins on developed film. (C) Densitometrically evaluated relative (in relation to GAPDH) intensity of Cbln1 protein expression. 1, zona glomerulosa; 2, zona fasciculata/reticularis; and 3, medulla. 


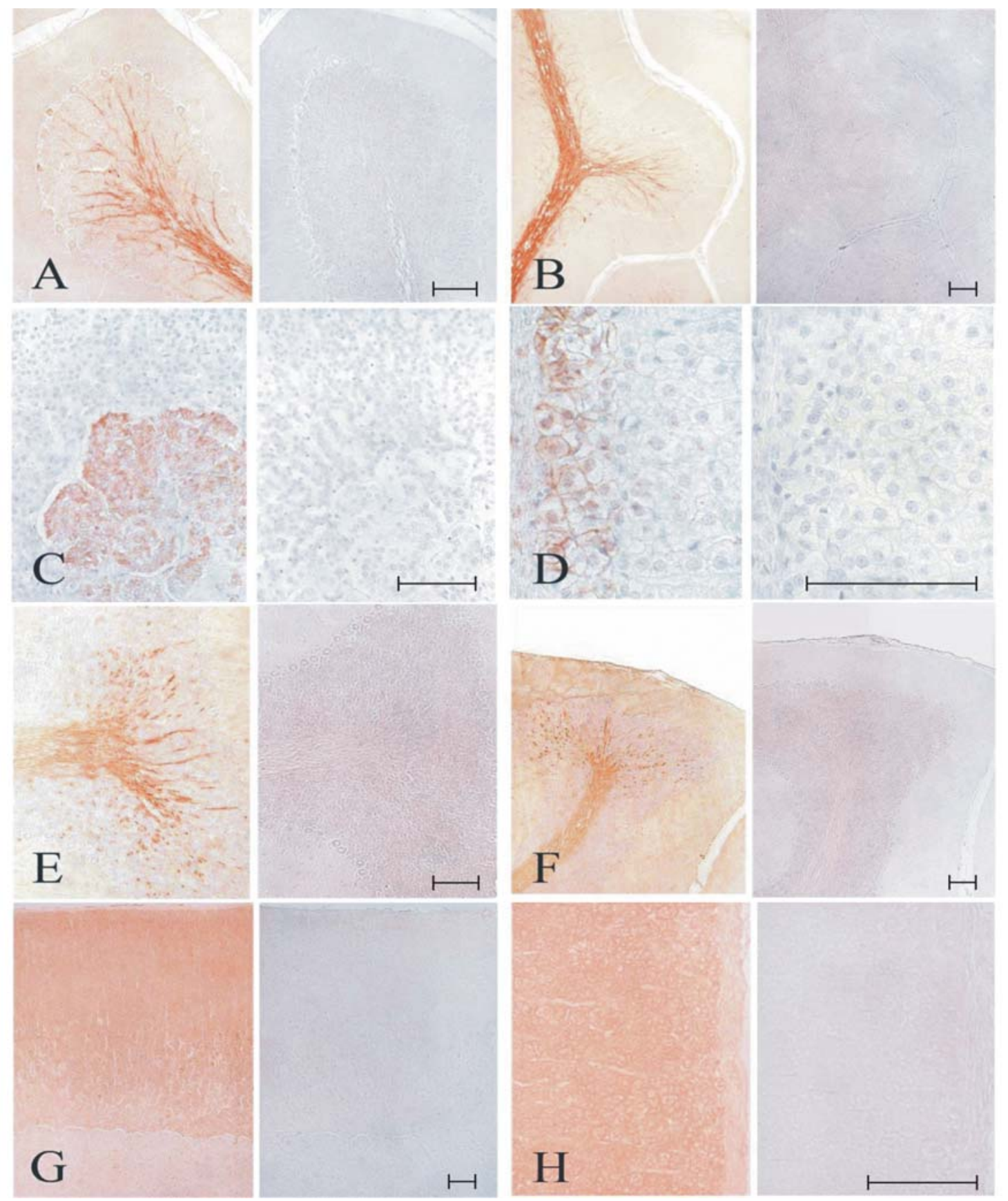

Figure 6. Localization of cerebellin-like (A-D) and precerebellin 1-like (E-H) immunoreactivities in the cerebellum (A, B, E and F) and adrenal gland (C, D, $\mathrm{G}$ and $\mathrm{H}$ ) of the adult male rat. Each pattern is accompanied by the appropriate control reaction (right). Nuclei counterstained with hematoxylin. Scale bar, $100 \mu \mathrm{m}$. A, B, E and F, cerebellum; C, adrenal medulla; D and H, adrenal zona glomerulosa; G, adrenal cortex and medulla.
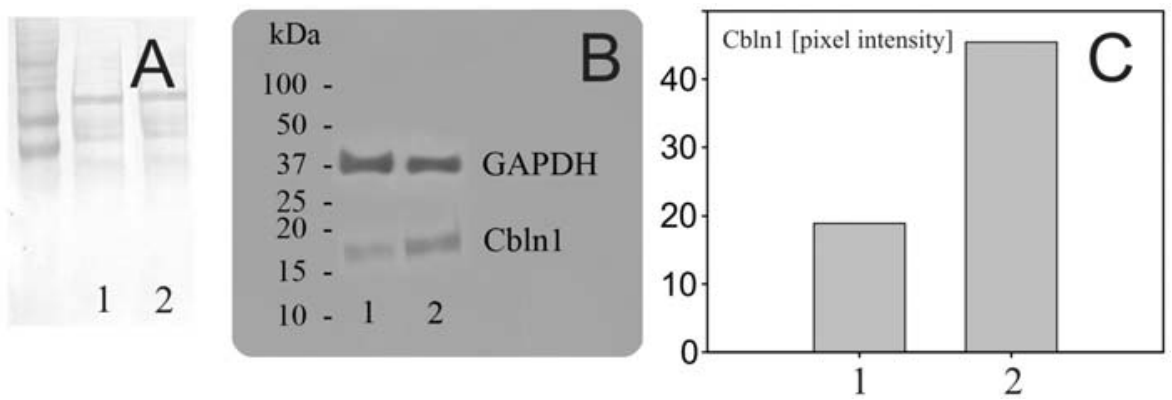

Figure 7. Semiquantitative evaluation of Cbln1 protein expression in extracts from the adrenal cortex of the adult male rat. (A) Western blotting. Proteins stained with Ponceau S. (B) Chemiluminescence signals of Cbln1 and GAPDH on developed film. (C) Densitometrically evaluated relative (in relation to GAPDH) intensity of Cbln1 protein expression. 1, proteins extracted with Tris buffer; 2, with RIPA buffer. 


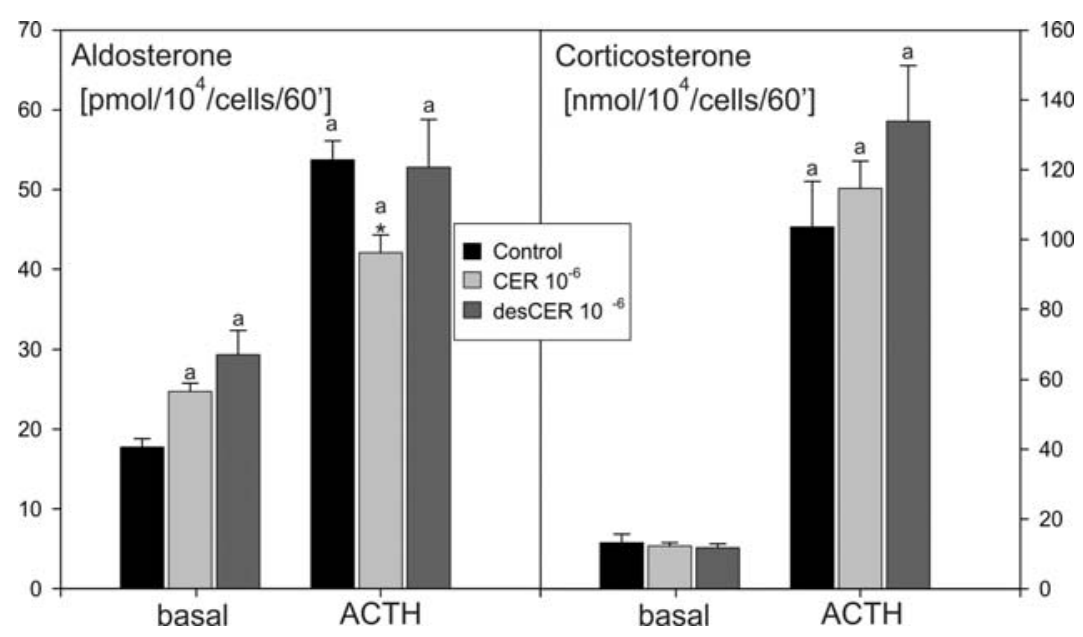

Figure 8. Effects of cerebellin (CER) and des-cerebellin (desCER) on basal and ACTH (1x10-7 M)-stimulated aldosterone (pmol/10 4 cells/60 min) secretion by isolated zona glomerulosa cells and corticosterone ( $\mathrm{nmol} / 10^{4}$ cells/60 $\mathrm{min}$ ) output by isolated zona fasciculata/reticularis cells of the rat adrenal cortex. Bars represent the means, and \pm SEM is shown. Each group, $n=6$. Statistical comparison of differences by the Student's t-test. Differences from the control group are significant at ${ }^{\mathrm{a}} \mathrm{p}<0.001$; differences from control ACTH group are significant at ${ }^{*} \mathrm{p}<0.01$.

RIPA buffer enables the extraction of both integral and peripheral membrane proteins while Tris buffer preferentially extracts peripheral proteins. Western blotting, performed as described above, identified Cbln1. Intensity of the Cbln1 band was higher in RIPA than in Tris protein extracts (Fig. 7).

We investigated the effects of CER and desCER on aldosterone and corticosterone secretion by freshly isolated rat adrenocortical cells. As evidenced by Fig. 8, at the concentration of $1 \times 10^{-6} \mathrm{M}$, both CER and desCER stimulated basal aldosterone secretion by isolated zona glomerulosa cells. In these cells, CER but not desCER, inhibited ACTHinduced $\left(1 \times 10^{-7} \mathrm{M}\right)$ aldosterone output. Neither CER nor desCER affected both basal and ACTH-evoked corticosterone output by freshly isolated fasciculata/reticularis cells.

\section{Discussion}

In agreement with our earlier observations, the present study confirmed expression of the Cbln(1-3) genes and Cbln1 protein in the rat adrenal gland $(16,25)$. On the other hand, expression of the Cbln4 gene was not found in the rat adrenal cortex while mRNA of this gene, as well as mRNAs of the remaining precerebellin genes (CBLN1-3), were present in a normal human adrenal cortex. This unexpected finding proposes questions on the role of $C B L N 4$ in the human adrenal cortex. In this regard, in previous studies, by means of Northern blot analysis or by RT-PCR, expression of the CBLN1 gene was not detected in normal human adrenal glands $(2,14,15)$. Concerning $C B L N 4$ gene expression, our data agree with the data presented by NCBI (NM_080617), in which the expression intensity of $C B L N 4$ in the human adrenal gland is listed in second place (after nervous tissue). Furthermore, since CBLN4 gene expression is present in the normal human adrenal cortex but not in the rat, the role of $C B L N 4$-related proteins does not seem to be connected with the regulation of steroidogenesis.

Previous studies on the localization of Cbln mRNA and CER or desCER in the human adrenal gland demonstrated their higher expression in the adrenal medulla than in the cortex (14). On the contrary, by means of classic RT-PCR, mRNAs for $C b \ln (1-3)$ were found to be present primarily in the rat adrenal cortex, but not in the medulla (25). Highest expression of the Cbln1 and Cbln 3 genes was demonstrated in the $\mathrm{ZG}$, lower expression in the $\mathrm{ZF} / \mathrm{R}$ and the lowest in the adrenal medulla. On the contrary, Cbln 2 gene expression was the highest in the $\mathrm{ZF} / \mathrm{R}$ and lower in the $\mathrm{ZG}$ and adrenal medulla. Thus, in the rat adrenal gland, expression patterns of Cbln1 and 3 were similar but different from that of Cbln2. Moreover, a similar pattern of Cbln1 expression was observed at the protein level (Western blotting and immunocytochemistry). In this regard, similar expression of the Cbln1 and 3 genes in adrenals suggests their similar regulation of expression while the similar pattern of Cbln mRNA and Cbln1 protein expression indicates that this regulation is primarily exerted at the transcription level.

We observed high expression of $\mathrm{Cbln}(1-3)$ also in isolated rat adrenocortical cells. Expression of the Cbln1 and 3 genes was higher in cells freshly isolated and incubated in KRBG for $60 \mathrm{~min}$, and expression of these genes was higher in ZG than in $\mathrm{ZF} / \mathrm{R}$ cells. These findings also suggest that in the rat adrenal cortex, both genes are not expressed in endothelial and connective tissue cells. Thus, the obtained data suggest that both genes are expressed in parenchymal cells of the rat adrenal cortex and this suggestion is confirmed by IHC. On the contrary, in freshly isolated $\mathrm{ZG}$ and $\mathrm{ZF} / \mathrm{R}$ cells, Cbln2 gene expression was notably lower than in intact gland and this may suggest that expression of the Cbln2 gene occurs also in interstitial tissue of the rat adrenal cortex.

Regarding intra-adrenal localization of Cbln 1 gene expression, IHC confirmed results obtained from experiments on isolated rat adrenocortical cells. CER- and Cbln1-like substances were found in axons of Purkinje cells while CERlike substances were observed in their perikaryons, thus confirming previous reports $(1,4,14,33-35)$. In the adrenals, Cbln1-like immunoreactivity was present mainly in the cortex of the gland, and the reaction products were noted 
both in the membranes and cytoplasm of parenchymal cells. CER-like immunoreactivity was also observed in membranes of the adrenal ZG cells, while in the medulla, immunoreactive substances were localized in the cytoplasm of chromaffin cells. Our results differ notably from previous data obtained on human adrenals, in which CER-like immunoreactivity was present primarily in the medulla of the gland (14). Membrane localization of Cbln1 is also suggested by the results of our experiments aimed to investigate the association of Cbln1 with the cell membrane, in which we found that intensity of the Cbln 1 protein band was higher in RIPA than in Tris protein extracts of adrenocortical cells.

We also examined the developmental regulation of expression of precerebellin-related genes in the rat adrenal cortex in the course of postnatal ontogenesis. Highest expression of the Cbln 1 and 3 genes was found in the adrenal cortex at days 2 and 90 of postnatal ontogenesis while Cbln2 gene expression at day 2 of life was significantly low and followed by higher and rather constant level of expression. As in the other experiments, in all days studied (days 2, 28, 45, 60, 90 and 360), we were not able to identify Cbln4 gene expression in the rat adrenal cortex. In the available literature, we found only one study reporting on expression of Cbln family mRNAs in the course of development. Studies on the mouse brain revealed that Cbln1, 2 and 4 mRNAs appear between days E10 and E13 and exhibit transient up-regulation during the late embryonic and neonatal periods (15). Cbln3 mRNA, on the other hand, was found to be present in cerebellar granular cells at postnatal days 7-10. This pattern of expression differs notably from that noted in the rat adrenal cortex and suggests organ- or species-specific control of precerebellin-related gene expression in the course of ontogenesis.

We also tested the ability of CER and desCER to modify corticosteroid secretion from freshly isolated rat adrenocortical cells. Initially, it was suggested that the N-terminal truncated version of CER, des-Ser1-CER, is an apparent metabolite of CER. However, recent data failed to confirm this contention $(1,34,36,37)$. In regards to the adrenal gland, both CER and desCER exert a modulatory effect on corticosteroid secretion (25,38-41). We also demonstrated a stimulating effect of CER and desCER (at the concentration $1 \times 10^{-6} \mathrm{M}$ ) on basal aldosterone secretion by freshly isolated rat zona glomerulosa cells. However, not only Cbln-derived polypeptides are biologically active compounds. Recently it was demonstrated that cells are able to secrete entire Cbln molecules which in extracellular space form homomeric and heteromeric complexes involved in paracrine or autocrine regulation of nervous cells, among others in synapse development and synaptic plasticity, especially in the cerebellum $(5,6,8,42)$. We cannot exclude that a similar mechanism of Cbln actions may operate in the adrenal gland.

Thus, the present study provided precise data on expression of the precerebellin-related genes and precerebellin 1 peptide in the adrenal gland of the rat and on their developmental regulation. Our findings open new research possibilities on the involvement of precerebellin-related genes in the regulation of the biological activity of the adrenal gland. We also found that, contrary to the human adrenal, in the rat adrenal gland, the Cbln4 gene was not expressed at the mRNA level.

\section{Acknowledgements}

This study was supported by a grant from the State Committee for Scientific Research (0220/P01/2006/30). Part of this research was carried out at the Department of Anatomy and Physiology, University of Padua, Italy with support from the Federation of European Biochemical Societies (FEBS) Short Term Fellowship. This research was conducted toward the partial fulfillment of the Ph.D. thesis requirement, Poznan University of Medical Sciences, Poznan, Poland, for Marcin Rucinski.

\section{References}

1. Slemmon JR, Blacher R, Danho W, Hempstead JL and Morgan JI: Isolation and sequencing of two cerebellum-specific peptides. Proc Natl Acad Sci USA 81: 6866-6870, 1984.

2. Urade Y, Oberdick J, Molinar-Rode R and Morgan JI: Precerebellin is a cerebellum-specific protein with similarity to the globular domain of complement C1q B chain. Proc Natl Acad Sci USA 88: 1069-1073, 1991.

3. Wada $\mathrm{C}$ and Ohtani $\mathrm{H}$ : Molecular cloning of rat cerebellin-like protein cDNA which encodes a novel membrane-associated glycoprotein. Mol Brain Res 9: 71-77, 1991.

4. Kavety B, Jenkins NA, Fletcher CF, Copeland NG and Morgan JI: Genomic structure and mapping of precerebellin and a precerebellin-related gene. Brain Res Mol Brain Res 27: 152-156, 1994.

5. Pang Z, Zuo J and Morgan JI: Cbln3, a novel member of the precerebellin family that binds specifically to Cbln1. J Neurosci 20: 6333-6339, 2000.

6. Iijima T, Miura E, Matsuda K, Kamekawa Y, Watanabe M and Yuzaki M: Characterization of a transneuronal cytokine family Cbln regulation of secretion by heteromeric assembly. Eur J Neurosci 25: 1049-1057, 2007.

7. Dicou E: Biologically active, non membrane-anchored precursors: an overview. FEBS J 275: 1960-1975, 2008

8. Yuzaki M: Cbln and C1q family proteins: new transneuronal cytokines. Cell Mol Life Sci 65: 1698-1705, 2008.

9. Petry F, Reid KB and Loos M: Molecular cloning and characterization the complementary DNA coding for the B-chain of murine C1q. FEBS Lett 258: 89-93, 1989.

10. Petry F, Reid KB and Loos M: Isolation, sequence analysis and characterization of cDNA clones coding for the $\mathrm{C}$ chain of mouse C1q. Sequence similarity of complement subcomponent C1q, collagen type VIII and type X and precerebellin. Eur J Biochem 209: 129-134, 1992.

11. Muragaki Y, Shiota C, Inoue M, Ooshima A, Olsen BR and Ninomiya Y: Alpha I(VIII)-collagen gene transcripts encode a short-chain collagen polypeptide and are expressed by various epithelial, endothelial and mesenchymal cells in newborn mouse tissues. Eur J Biochem 207: 895-902, 1992.

12. Elima K, Eerola I, Rosati R, Metsaranta M, Garofalo S, Perala M, De Crombrugghe $\mathrm{B}$ and Vuorio $\mathrm{E}$ : The mouse collagen $\mathrm{X}$ gene: complete nucleotide sequence, exon structure and expression pattern. Biochem J 289: 247-253, 1993.

13. Takachashi K, Totsune K and Murakami O: Adrenocortical peptides: autocrine or paracrine regulators for the steroid hormone secretion or the cell proliferation? Exp Clin Endocrinol Diabetes 110: 373-380, 2002.

14. Satoh F, Takahashi K, Murakami O, Totsune K, Ohneda M, Mizuno Y, Sone M, Miura Y, Takase S, Hayashi Y, Sasano H and Mouri T: Cerebellin and cerebellin mRNA in the human brain, adrenal glands and the tumour tissues of adrenal tumour, ganglioneuroblastoma and neuroblastoma. J Endocrinol 154: 27-34, 1997

15. Miura E, Iijima T, Yuzaki M and Watanabe M: Distinct expression of Cbln family mRNAs in developing and adult mouse brains. Eur J Neurosci 24: 750-760, 2006.

16. Rucinski M and Malendowicz LK: Precerebellin-related genes and precerebellin 1 peptide in endocrine glands of the rat pattern of their expression. Int J Mol Med 23: 113-119, 2009.

17. Hinson JP, Kapas S, Orford CD and Vinson GP: Vasoactive intestinal peptide stimulation of aldosterone secretion by the rat adrenal cortex may be mediated by the local release of catecholamines. J Endocrinol 133: 253-258, 1992. 
18. Malendowicz LK, Macchi C, Nussdorfer GG, Nowak KW, Ziolkowska A, Trejter M and Ginda W: Inhibitory effect of cerebellin on rat thyroid gland. Biomed Res 22: 99-101, 2001.

19. Malendowicz LK, Neri G, Markowska A, Hochol A, Nussdorfer GG and Majchrzak M: Effects of leptin and leptin fragments on steroid secretion of freshly dispersed rat adrenocortical cells. J Steroid Biochem Mol Biol 87: 265-268, 2003.

20. Ziolkowska A, Rucinski M, Di Liddo R, Nussdorfer GG and Malendowicz LK: Expression of the beacon gene in endocrine glands of the rat. Peptides 25: 133-137, 2004.

21. Ziolkowska A, Belloni AS, Nussdorfer GG, Nowak M and Malendowicz LK: Endocrine disruptors and rat adrenocortical function: Studies on freshly dispersed and cultured cells. Int J Mol Med 18: 1165-1168, 2006

22. Ziolkowska A, Tortorella C, Nussdorfer GG, Rucinski M, Majchrzak M and Malendowicz LK: Accumulation of steroidogenic acute regulatory protein mRNA, and decrease in the secretory and proliferative activity of rat adrenocortical cells in the presence of proteasome inhibitors. Int J Mol Med 17: 865-868, 2006.

23. Andreis PG, Tortorella C, Ziolkowska A, Spinazzi R, Malendowicz LK, Neri G and Nussdorfer GG: Evidence for a paracrine role of endogenous adrenomedullary galanin in the regulation of glucocorticoid secretion in the rat adrenal gland. Int J Mol Med 19: 511-515, 2007.

24. Albertin G, Rucinski M, Carraro G, Forneris M, Andreis P, Malendowicz LK and Nussdorfer GG: Adrenomedullin and vascular endothelium growth factor genes are overexpressed in the regenerating rat adrenal cortex, and AM and VEGF reciprocally enhance their mRNA expression in cultured rat adrenocortical cells. Int J Mol Med 16: 431-435, 2005.

25. Rucinski M, Albertin G, Spinazzi R, Ziolkowska A, Nussdorfer GC and Malendowicz LK: Cerebellin in the rat adrenal gland: gene expression and effects of CER and [des-Ser1]CER on the secretion and growth of cultured adrenocortical cells. Int J Mol Med 15: 411-415, 2005

26. Rucinski M, Ziolkowska A, Neri G, Trejter M, Zemleduch T, Tyczewska M, Nussdorfer GG and Malendowicz LK: Expression of neuromedins $\mathrm{S}$ and $\mathrm{U}$ and their receptors in the hypothalamus and endocrine glands of the rat. Int J Mol Med 20: 255-259, 2007.

27. Rucinski M, Zok A, Guidolin D, De Caro R and Malendowicz LK: Expression of precerebellins in cultured rat calvaria osteoblastlike cells. Int J Mol Med 22: 553-558, 2008.

28. Ziolkowska A, Rucinski M, Tortorella C, Tyczewska M Nussdorfer GG and Malendowicz LK: Cultured rat calvarial osteoblast-like cells are provided with orexin type 1 receptors. Int J Mol Med 20: 779-782, 2007.

29. Markowska A, Neri G, Hochol A, Nowak M, Nussdorfer GG and Malendowicz LK: Effects of leptin and leptin fragments on steroid secretion and proliferative activity of regenerating rat adrenal cortex. Int J Mol Med 13: 139-141, 2004.
30. Hochol A, Albertin G, Nussdorfer GG, Spinazzi R, Ziolkowska A Rucinski M and Malendowicz LK: Effects of neuropeptides B and $\mathrm{W}$ on the secretion and growth of rat adrenocortical cells Int J Mol Med 14: 843-847, 2004

31. Ziolkowska A, Macchi C, Trejter M, Rucinski M, Nowak M, Nussdorfer GG and Malendowicz LK: Effects of neuromedin-U on immature rat adrenocortical cells: In vitro and in vivo studies. Int J Mol Med 21: 303-307, 2008.

32. Trejter M, Neri G, Rucinski M, Majchrzak M, Nussdorfer GG and Malendowicz LK: Neuromedin U stimulates enucleationinduced adrenocortical proliferation in the rat. Int J Mol Med 21: 683-687, 2008

33. Mugnaini E and Morgan JI: The neuropeptide cerebellin is a marker for two similar neuronal circuits in rat brain. Proc Nat Acad Sci USA 84: 8692-8696, 1987.

34. Burnet PWJ, Bretherton-Watt D, Ghatei MA and Bloom SR: Cerebellin-like peptide: Tissue distribution in rat and guinea-pig and its release from rat cerebellum, hypothalamus and cerebellar synaptosomes in vitro. Neuroscience 25: 605-612, 1988.

35. Morgan JI, Slemmon JR, Danho W, Hempstesd J, Berrebi AS and Mugnaini E. Cerebellin and related postsynaptic peptides in the brain of normal and neurodevelopmentally mutant vertebrates Synapse 2: 117-124, 1988

36. Slemmon JR, Danho W, Hempstead JL and Morgan JI: Cerebellin: a quantifiable marker for Purkinje cell maturation. Proc Natl Acad Sci USA 82: 7145-7148, 1985.

37. Yiangou Y, Burnet P, Nikou G, Chrysanthou BJ and Bloom SR: Purification and characterisation of cerebellins from human and porcine cerebellum. J Neurochem 53: 886-889, 1989.

38. Mazzocchi G, Andreis PG, De Caro R, Aragona F, Gottardo L and Nussdorfer GG: Cerebellin enhances in vitro secretory activity of human adrenal gland. J Clin Endocrinol Metab 84: 632-635, 1999.

39. Albertin G, Malendowicz LK, Macchi C, Markowska A and Nussdorfer GG: Cerebellin stimulates the secretory activity of the rat adrenal gland: in vitro and in vivo studies. Neuropeptides 34: 7-11, 2000

40. Malendowicz LK, Hochol A, De Caro R, Trejter M, Markowska A Nussdorfer GG and Nowak M: Effect of cerebellin on the pituitary-adrenocortical function in adult rats and the proliferative activity of immature and regenerating rat adrenal cortex. Biomed Res 21: 85-88, 2000.

41. Hochol A, Neri G, Majchrzak M, Ziolkowska A, Nussdorfer GG and Malendowicz LK: Prolonged cerebellin administration inhibits the growth, but enhances steroidogenic capacity of rat adrenal cortex. Endocr Res 27: 11-17, 2001.

42. Bao D, Pang Z and Morgan JI: The structure and proteolytic processing of Cbln1 complexes. J Neurochem 95: 618-629, 2005. 